\title{
CARE LEAVERS' PERSPECTIVES ON THE FAMILY IN THE TRANSITION FROM OUT-OF-HOME CARE TO INDEPENDENT LIVING
}

\section{Stephan Sting and Maria Groinig}

\begin{abstract}
Findings from youth research have shown that, due to the development of the transitional phase of "emerging adulthood", the family has become increasingly significant for young adults as a source of support and as a safety net. In contrast, care leavers are confronted with a relatively abrupt transition to independent living. However, international studies have shown that the family also plays a significant role during the status passage of leaving care — as an arena of concrete social relationships, as a normative model and ideal, as a biographical experience and memory, as a connection to family traditions and practices, and as an important contextual factor for resilience and identity formation. The first section of this paper describes the various links between care leavers and their families based on a literature review. In the second section, the biographical relevance of the family is highlighted based on the example of a qualitative interview study about the educational pathways of 20- to 27-year-old care leavers. The study shows the various influences of family links on the educational careers of young people during and after out-of-home care. From the findings, we derive some consequences for professional work with families in out-of-home care and for professional support and guidance during the status passage of leaving care.
\end{abstract}

Keywords: care leaver, family, out-of-home care, transition to adulthood

Stephan Sting PhD (corresponding author) is a Professor of Social Pedagogy in the Department of Educational Science at the University of Klagenfurt, Universitaetsstrasse 65-67, A-9020 Klagenfurt, Austria. Email: Stephan.Sting@aau.at.

Maria Groinig MA is a research assistant in the field of Social Pedagogy at the University of Klagenfurt, Universitaetsstrasse 65-67, A-9020 Klagenfurt, Austria.

Email: Maria.Groinig@aau.at. 
Findings in youth research show that the status ascribed to the family during the transition from youth to adulthood has changed in recent decades. For young people in highly developed societies, like that of Austria, the pluralisation of lifestyle choices, uncertainty during biographical transitions, and more demanding educational requirements have extended the phase of youth, or even blurred its boundaries (Schröer, 2011), making young people dependent on their family for longer. One sign of this is the pan-European trend towards young people living with their parents for longer (Statista, 2019). The transitional phase between attaining legal adulthood at the age of 18 until the age of roughly 25 has become known as "young adulthood" (Stauber \& Walther, 2013) or "emerging adulthood" (Arnett, 2000). This features discontinuous, unstructured, and sometimes reversible transition processes (Schröer, 2013, p. 70; Weinhardt, 2014), which give young people space to develop and try out lifestyle choices (Hurrelmann \& Quenzel, 2016, p. 35), make attempts at higher education, and, in tackling these challenges, contribute to their personal development and establish social affiliations.

In this phase, when family supports are an important "safety net" and backup (Großegger, 2011), young people receive differing degrees of financial, practical, social, and emotional support from their birth families. This often leads to a redefinition of their family relationships (Arnett, 2019), and increases the burden on family resources. When families are unable to provide extended support, young people are thrown back on their own resources for coping with the transition process (Ward, 2008).

This is especially the case for "care leavers" - adolescents or young adults who have grown up for at least part of their lives outside their birth family in residential care or foster families and are setting off on the path to adulthood from that starting point (Thomas, 2013; Care Leavers' Association, 2019). This definition implies that they have complicated relationships with their birth families. Typical reasons for being in care include stressful or even traumatising experiences in the family of origin, such as neglect, violence, abuse, the parents' inability to raise or care for their children, or even parental absence. Care leavers transition to adulthood at a distance from their families, though the specific relationships they have with their birth families vary greatly. One thing they all have in common, however, is their experience of youth welfare, which becomes part of their family history and needs to be processed in the context of family relationships (Collins et al., 2008).

In Austria, as in many countries, young people in youth care are generally expected to transition to independence at the age of 18, a transition that has been described as "instant adulthood" (Sulimani-Aidan, 2018). This abrupt change is linked to a limited range of lifestyle options, a greater number of biographical risks, and the threat of social exclusion (e.g., Arnett, 2007; Häggman-Laitila et al., 2018; Refaeli, 2017; Stein, 2008). As a consequence, care leavers are confronted with a discrepancy between their situation in life and that of their peers in the general population that amounts to a structural disadvantage affecting different areas of their lives. 
International Journal of Child, Youth and Family Studies (2020) 11(4.2): 140-159

Youth care workers preparing youth for independence place a strong focus on "living alone" (Sievers et al., 2015, p. 41). Care leavers themselves consider their ability to live independently and be self-reliant a key success factor in the status passage of leaving care (Sulimani-Aidan, 2018; Driscoll, 2013). It has been argued that this self-image of being independent and self-reliant may belong to a pattern of "pseudo-independence" that youth from care use to avoid future attachments and to mask their social isolation (Mann-Feder, 2019, p. 15), yet living alone itself may engender feelings of loneliness and social isolation (Gradaílle et al., 2018; Sulimani-Aidan \& Melkman, 2018). Internationally, there are differing degrees of professional support for the time after care. In Austria, programmes for care leavers are few and fragmentary as yet. Stable social relationships with people outside youth welfare are relatively uncommon amongst young people who have spent time in care (Theile, 2015, pp. 230-231). Care leavers often experience the absence of a safety net (Mendes et al., 2014). Accordingly, during the status passage of leaving care, the "quest for social and emotional care" proves to be a central principle guiding care leavers' actions (Groinig \& Sting, 2019 , p. 44). Numerous international studies have shown that, in this situation, the family increasingly comes to the fore again in various ways (e.g., Collins et al., 2008; Gradaílle et al., 2018; Refaeli, 2017; Theile, 2015; Wade, 2008).

The various links of care leavers to their families are described below in a review of the international literature. The subsequent section is based on a qualitative study of the educational pathways taken by care leavers in Austria. It points out the biographical relevance of the family through examples of its influence on the educational careers of young people during and after outof-home care. The final discussion examines the implications of our analysis with regard to professional work with families in out-of-home care, and for support and guidance during the status passage of leaving care.

\section{Literature Review}

The transition from out-of-home care to independent living has been described as a biographical "turning point" and a phase of reevaluating life orientations and social ties (Driscoll, 2013; Wade, 2008). When searching for sustainable relationships, care leavers often turn to family members, resurrecting complicated family circumstances. The extent to which the family is perceived as either a form of social support or a burden seems to have a significant impact on subjects' future prospects and chances of successfully coping with life (Häggman-Laitila et al., 2018). In this context, the family can be conceptualised in various ways: as a biological family of origin, as a social construction of the family in the sense of "doing family" (Jurczyk et al., 2014), as an extended family in which more distant relatives may become important attachment figures apart from the nuclear family (Schmidt \& Moritz, 2009, p. 61), or as an action-guiding image and normative model that influences everyday practices and actions (Bauer et al., 2015). 
International Journal of Child, Youth and Family Studies (2020) 11(4.2): 140-159

\section{Relationships With the Family of Origin}

When young people turn back towards their family during the status passage of leaving care, this is accompanied by a reevaluation of their relationship with their birth family. Despite negative experiences, their biological parents still have a central place in their social network (e.g., Mendes et al., 2012; Nestmann et al., 2008; Theile, 2015). Even in problematic family constellations, there still seems to be a "general supply of support" (Menz, 2009, pp. 194, 242). Equally, in socially disadvantaged contexts there are still aspirations to "being a good mother" or "effective parenting", even if these do not always coincide with dominant social norms and may thus come into conflict with the youth welfare system (Adjei \& Minka, 2018; Narciso et al., 2018). With this in mind, the link to the birth family may promise support in the light of biographical risks such as imminent homelessness, and is also associated with the hope that the relationship with the family could improve (Collins et al., 2008; Wade, 2008).

Studies by Collins et al. (2008), Mendes et al. (2012), and Wade (2008) have shown that although only a few care leavers actually return to their family of origin, they do connect to and maintain contact with family members in a variety of ways. Wade concluded that contact intensifies in the course of the status passage of leaving care. Refaeli (2017), however, pointed to the need to distinguish between family relationships and family support. While relationships with family members are not unusual, there tends to be little actual family support (Marion \& Paulsen, 2019). Most family relationships remain conflictual or are accompanied by ongoing resentments (Collins et al., 2008; Gradaílle et al., 2018; Mendes et al., 2012). In some cases, the care leavers are themselves required to support family members (Sulimani-Aidan \& Melkman, 2018). Various studies have shown that members of the birth family are not usually "active agents" in developing future-oriented motivations and goals (Sulimani-Aidan, 2018), but are more likely to act as a source of stress (Driscoll, 2013; Refaeli, 2017).

In some cases, turning back towards the family can lead to the reenactment of family conflicts and critical events (Sievers et al., 2015, p. 38), or to the care leavers themselves breaking off contact. When there is a definitive break with the family of origin, it is generally preceded by experiences of rejection and disappointment, neglect, traumatisation, or emotional abuse (Wade, 2008).

\section{Construction of Family in the Sense of "Doing Family"}

Young people who have been in care are characterised by heterogeneous family experiences that often do not correspond to normative models and ideals of the family. At the same time, structural changes to the family in general mean that traditional family forms, family roles, and everyday family-related practices have altered (e.g., Brake \& Büchner, 2011, pp. 145-146; Lange \& Xyländer, 2011, pp. 66-68; Peukert, 2007, pp. 40-42). With this in mind, Jurczyk (2014) developed the concept of "doing family", in which the family is understood as a social construction: family is a historically and culturally variable system produced by the family members' social practices, the most relevant of which are daily practices of care and the 
construction of affiliation. The concept has now been taken up in the context of youth welfare to reflect idealised and normalist expectations of the family, and to direct the focus towards specific private and professional forms of care and constructions of affiliation. Taking the example of family-like forms of care, Eßer and Köngeter (2012) showed how forms of belonging are produced through daily practices and developing a history of affiliation. They revealed how care is manifested as the establishment of a comprehensive framework extending from satisfying basic needs to looking after the sick, encouraging school education, and arranging leisure activities.

Maack (2013) studied how care leavers have developed their own understanding of the family according to which, for example, carers, youth welfare workers, or even other young people at a placement can become their "new family". Equally, they may manage to bring in people offering informal support, such as neighbours, or caretakers, as part of their family construction (Groinig et al., 2019, pp. 162-163). However, relationships of this kind, just like those with professional carers, are all temporally limited and revocable (Maack, 2013), setting them apart from family relationships, which tend to be indissoluble and irrevocable (e.g., Kasten, 2003, p. 21; Schneewind, 2010, p. 194). Moreover, when professional relationships are being formed in youth welfare institutions, professionals emphasise the need to balance closeness and distance, which prevents such relationships from replacing the functions of a family (e.g., Dörr \& Müller, 2012, pp. 8-9; Thiersch, 2012, p. 38). Accordingly, during the status passage of leaving care, contact with family members often grows stronger over time, whereas contact with other attachment figures, such as foster parents and professional carers, weakens relatively quickly (Wade, 2008).

\section{Status of Family Members From the Perspective of an Extended Family}

There is ample evidence that young people who have been in care distinguish between extended family constructions and family members with whom they are related. The children surveyed in Leitner et al.'s 2011 study on sibling relationships in SOS Children's Village families showed that, even though the children are cared for in a family-like manner, they clearly differentiated between biological and social sibling relationships, according biological siblings a prominent status in their social network (pp. 161-162).

Once they have transitioned to independent living, care leavers seem to be guided to a large extent by their families, with a wide range of family members taking on the role of attachment figures. Siblings and birth mothers seem to come first as key persons, followed by birth fathers, grandparents, uncles and aunts, and other relatives (Wade, 2008). Attar-Schwartz and Huri (2019) emphasised the fact that, even during residential care, members of the extended family were fulfilling the role of attachment figures to an extent that had previously been underestimated: when the birth parents are absent, this extended family seems to be an important source of social support. It seems likely that family members such as grandparents and siblings (Sting, 2014) continue to play a significant role as supportive figures even after the status passage of leaving care.

Care leavers thus seem to create a link to their family that does not so much follow the model of a bourgeois nuclear family as the model of an extended family in which heterogeneous 
relationship constellations can develop. The concept of the extended family includes the idea that although its members are physically separated, the family contains relevant relationship and support structures (Schmidt \& Moritz, 2009, p. 61; Segalen, 2009, p. 61). A connection to their extended family seems to be of particular relevance to those care leavers who have experienced conflicts with their parents. Focusing on the extended family does not relieve them of the need to "do family". It shows, however, that members of their birth family and other kin play a particular role in family constructions, because they are associated with implicit expectations of loyalty and solidarity (Kasten, 2003).

\section{The Role of "Images of the Family" in Guiding Care Leavers' Actions}

Examination of the explicit expectations that care leavers hold about family members reveals that their connection to the family contains an imaginary component based on their notions and images of the family. The concept of "images of the family" refers to linguistic and imagined

representations of and about the family (Bauer et al., 2015, pp. 16-17) that are based on normative models and become a canvas for projected hopes and fears. They are also an expression of care leavers' own experiences with their families, and help individuals develop identities that position them specifically in the context of family generations (Bauer \& Wiezorek, 2017, p. 8). Finally, they are used in the cultural reproduction and transformation of familial communities, by taking on the form of a "collective memory" (Cyprian, 2003, p. 10).

For young people who have transitioned from care to independent living, the mixture of factual experiences, normative ideals, and collective memories that make up their images of the family have an action-guiding role that can influence their everyday practices. On one hand, the power of these images of the family (Bauer et al., 2015, p. 17) is rooted in legal regulations that, for example, require care leavers to give their parents financial support when needed, or that make funding for further education dependent on their parents (Care Leaver e.V., 2019). On the other hand, images of the family can develop an imagined power that continues to have an effect even when ties to the family have been cut off. Refaeli (2017) pointed to the example of a young man who broke off contact with his family after leaving care due to traumatising experiences and negative feelings. Despite this, he brought up links to the family memory that guided his actions: "He mentioned that joining the fire department was a family tradition that he decided to perpetuate" (Refaeli, 2017, p. 6). This gives him access to a stabilising social environment.

Care leavers have often experienced many biographical ruptures and discontinuities. The fact that family relationships are lasting and unquestioned despite periods of lack of contact seems to give young people who have spent time in care a feeling of continuity and affiliation; this "sense of permanency" is conducive to their healthy development and identity construction (Collins et al., 2008). Family relationships have been recognised as "identity capital" (Mann-Feder, 2019, p. 16) and as an important element of "social capital" that predicts positive outcomes and resilience in the status passage of leaving care (van Breda \& Dickens, 2017). Conversely, Stein (2008) identified the lack of a "sense of family" and a failure to understand damaging experiences with 
the family as the main barriers to identity construction and to having the ability to "psychologically 'move on' and look to the future" after leaving care (p. 295). In the transition to independent living, imagined and real family relationships thus seem to form a central basis for processes of selfeducation and the establishment of social affiliations.

One way of "doing family" is to enter into a partnership and start a new family. After the transition, images of the family can act as ideals or objectives that lead young people to construct an "alternative home base" in an attempt to make up for negative experiences with their families of origin and counter the risks of loneliness and social isolation (Wade, 2008). At this stage, however, partnerships often prove to be unstable. Alongside a partnership, parenthood also offers them a means of establishing social affiliation. Statistical studies show that on average, care leavers become parents earlier than peers who have not been in care (Cameron et al., 2018). In such cases, care leavers are trying to become emotionally significant to someone else, as well as trying to demonstrate "normality" by living up to the normative ideal of the nuclear family (Wade, 2008).

Attempting to enact their idealised image of the family in this way brings risks to care leavers, which have been discussed in terms of the problems of teenage parenting and the transgenerational propagation of dependence on the youth welfare system (Knight et al., 2006). Nonetheless, it also offers opportunities to start afresh, doing things differently or better than their own parents. Parenting creates feelings of being needed and of living a meaningful life, feelings that may be experienced positively and help strengthen the personality. Equally, it sometimes improves the care leaver's relationship with his or her birth family (Wade, 2008).

In cases where a positive connection to the family of origin is difficult or impossible due to a negative history, confrontation with the family - especially parents - can nonetheless be an important motivating factor for a care leaver's future way of life: the parents' difficult situation in life is seen as a "mirror image" to be avoided when planning a "possible future" (Sulimani-Aidan, 2018, p. 74). The stage of emerging adulthood opens up a "window of opportunity" (SulimaniAidan \& Melkman, 2018, p. 136) for them to pursue a different life path from their parents' negative example. The precedent set by a care leaver's parents becomes an important reference point for developing the care leaver's own life goals and expectations, and a catalyst for their efforts to educate themselves (Groinig et al., 2019, p. 147).

In other words, by drawing on images of the family care leavers can see various possible ways to live their lives. Despite the risk that hanging onto counterfactual ideals may lead to disappointment, these images offer care leavers a potential means of maintaining and developing social affiliations and a chance to make their own life plans, deviating from their biographical experiences with their birth families. As yet, little is known about how likely these efforts are to succeed. 
International Journal of Child, Youth and Family Studies (2020) 11(4.2): 140-159

\section{The Present Study: Educational Pathways of Care Leavers}

The following section reveals how family relationships affect future life outcomes, using the example of their influence on care leavers' educational pathways. Educational success is an increasingly vital means of acquiring and maintaining social status, which has simultaneously altered the social significance of family. In contrast, those who stumble on the educational pathway risk exclusion and disadvantages later in life (Steiner et al., 2016, p. 176). Against this background, a new, implicit expectation has developed in modern society that parents and responsible attachment figures are obligated to guarantee their children's education; the family and parents are now seen as an educational resource (Richter, 2016). However, in the family networks of young people with experience of youth care (often known as "troubled families") conditions are usually unfavourable for putting them on a positive educational path (Hücker, 2014).

\section{Research Design}

The role that the family plays in care leavers' educational pathways was examined in the study "Educational opportunities and how social contextual conditions affect care leavers' educational biographies", which was conducted at Klagenfurt University (Groinig et al., 2019). We carried out a qualitative biographical sub-study, as reported in Groinig \& Sting (2019), in which interviews were held with 23 care leavers aged 20 to 27 who had experienced residential care in different regions of Austria. To collect the data, we used problem-centred, semi-structured interviews

combining unstructured biographical narratives with focused questions (Witzel, 2000). The interviews were complemented by the creation of "egocentric network diagrams" (Hollstein, 2006), which were used to generate further narratives about the relevance of different people (e.g., family members) in the care leavers' networks. The data analysis was based on the documentary method (Bohnsack et al., 2007; Bohnsack et al., 2010; Nohl, 2017). The documentary method is a reconstructive hermeneutic procedure for working out central action-guiding orientation frameworks. To carry out this procedure, as we reported in Groinig \& Sting (2019):

"focusing metaphors" (Bohnsack, 2010, p. 105) were reconstructed. These are culminating points in the storyline of reported experiences with social contexts such as families, youth welfare facilities, schools, or peer groups. They were found by analysing emphasised and repeated statements in individual interviews or by comparing different cases. The focusing metaphors relate to a specific focal group's "centres of common experience". (p. 44)

People who share a biographic experience have a common experiential space that is "documented" in interaction and discourse. For example, care leavers often described the experience of their educational aspirations having been restrained in their families of origin. In the interviews, this experience was not only reported verbally, but was also evident in the structure of the interviews as narratives that received particular emphasis or were mentioned repeatedly by interviewees. By this means, the study analysed the effect that different social contexts had on care 
leavers' educational pathways. Below, selected findings from the study are presented that shed light on how the family shapes educational journeys.

Regarding the respondents' families of origin, it can be said that most of the young people had parents with low scholastic and vocational qualifications. But some of the young adults who were interviewed had far outstripped their parents' level of education: the sample of our study was part of the general development of education taking place throughout society, which sees younger generations aiming for higher educational qualifications than their parents.

\section{Results}

\section{Education-related Experiences in the Family of Origin}

In all of the cases we examined, the young people's families of origin were found to provide no support on their educational pathway. None of the families supported their scholastic achievement in the home, or noticeably valued formal education; instead, family stressors prevented them from performing as required by the schools. For example, as Verena's single mother was overtaxed, Verena took on the role of a housekeeper and looked after her sisters, which had a negative effect on her schooling ${ }^{1}$ :

I couldn't do my homework because there were five of us children in all. I, um, I didn't have my own room. There was constant chaos. So I always had to clean up and help out at home. Um, I was the second child, and we, me and my older sister, had to look after the younger ones too, because my mother was constantly, utterly overwhelmed. (Verena, lines 493-497)

In these family contexts, it is generally not possible for the family of origin to support the children when it comes to meeting the demands of schoolwork, as there is too much to deal with and too many everyday stressors. At the same time, a lack of interest in education or even a disparaging attitude towards educational aspirations can act as a hindrance. Zoey, for example, saw her father as preventing her from achieving her educational goals. The family lived in an area where, Zoey stated, "there are mainly poorly educated people" and where "no one ever talked about school or anything". After moving to a group home for young people, Zoey developed an independent commitment to education. With the support of a care worker and the youth welfare institution, she gained the Matura, the qualification required to enter higher education. She then decided to start studying. However, to do so, she relied on financial contributions from her family of origin, and had to deal with her father's disparaging and emotionally stressful attitude:

That he just says, right, to me, "Yeah, I shouldn't think I'm something special just because I have the Matura." And yeah. ... Afterwards he said what a cheek I have

\footnotetext{
${ }^{1}$ All names used to present the findings are pseudonyms chosen by the interviewees themselves.
} 
International Journal of Child, Youth and Family Studies (2020) 11(4.2): 140-159

going to university full-time afterwards.... and then he actually has to pay for it.

Yes, nothing productive ever came from him. (Zoey, lines 113-119)

Her father himself had completed an apprenticeship as an electrician but was unemployed at that time. Zoey portrayed her mother as an alcoholic with the minimum required level of schooling who had died when Zoey was 21. During the interview, Zoey indicated that there was some ongoing contact with her family, but that she did not get on well with them.

The empirical material makes it clear that some of the people interviewed used their experiences with their family as a negative example that motivated them to dissociate themselves and follow a different path. Verena commented, "Well, one positive influence on ... my ... career was actually the realisation that I didn't want to be like my family" (line 900).

The children's efforts to distance themselves from their families of origin spurred them to become more committed to their own educational pathways. In Zoe's case, a gender-specific aspect appeared when she indicated that she wanted to become an independent woman, in contrast to her mother. For her, acquiring formal educational qualifications seemed to be the key to an independent life that would not correspond to the role models provided by her family of origin:

That's why I always just did a lot to make sure I didn't end up like that. Like Mum, who ... simply always depended on men. Afterwards I thought, "I don't want to live like that." Or "I never want to have a man so as to be able to afford anything." (Zoey, lines 1545-1546)

The examples show that in these families, support in coping with educational needs and educational aspirations did not come into the picture. One exception is Pascal, whose mentally ill mother was overwhelmed with his upbringing and who herself had only low qualifications, but who, according to Pascal, described her son as a "bright lad who'll study one day". Pascal shared her aspiration and indicated in his biographical narrative that if he dropped out of education it would probably have been a bitter disappointment to his mother. He was the only one in the sample to have taken a relatively straightforward path from school to university.

\section{Stances Towards the Family and Their Influence on Educational Pathways}

Consistent with the conceptualisations of the family outlined in the first section of this article, care leavers making the transition to independent living took up different positions towards their families of origin and these positions influenced their educational paths.

In some cases, the family became an imaginary reference point, an ideal or model that either reproduced their own familial experiences or acted as an aspirational family arrangement differing from that of their family of origin. Mike, for example, looked back on a positive family childhood

in which his father stood out as playing a central role. He was treated like a "little prince" who did not have to achieve educational success to gain his family's respect. When Mike was 12, his father fell ill and died; this led to the family losing their apartment and falling apart. From then on, Mike 
lived on the street, in shared supported housing, and finally in a homeless shelter. He left school without a diploma after completing compulsory education. At the time of the interview, he was not yet over the loss of his family of origin, and dreamt of a "divine intervention" - a stroke of good fortune that would help him achieve his idealised image of a harmonious family life:

But at some point in my life I might come across a nice family or a wife or later a child. That might happen. In life, I know, the way I see it, if you have a wife and child, God gives you everything. And that's how I'm going to do it. And I want a job. (Mike, lines 219-223)

Unlike Mike, Martin rejected the low educational aspirations of his family of origin. According to him, his family were "all labourers or unemployed" for generations. When he was in youth care as a child, he talked about wanting to be a doctor and was confronted with stigmatisation and demotivating comments based on his origins:

How could I ever become a doctor when my two parents are losers, in quotation marks ... Back then, as a child, I always dreamt of becoming a doctor, but I was always talked out of it: "Forget it. You have to learn a lot, learn a lot, and you have no aptitude for that." (Martin, lines 1042-1044)

At the time of the interview, Martin had been living for several years in a new family of his own with his girlfriend and their child. In these new family circumstances, his girlfriend supported him on his educational pathway, which he was continuing at evening school alongside his job:

She tries to encourage me to just keep on going, just that I could easily go to university [brief sigh] even though in the past people always said, "You — you idiot, you'll never make it." (Martin, lines 827-829)

The educational path of Pascal, a care leaver who had maintained a positive relationship with his mother, was shaped early on by the division of roles in the sense of "doing family". Although he could not grow up in his mother's home he visited her every weekend, but did not receive any support from her in school matters. Pascal explained that on the weekends, "everything was just quite unacademic"; instead, it was the caregivers in the youth welfare institution who "took on the parental role" and "kept ... things moving ahead at school". When it came to getting through the Matura exam (to enter higher education), he was also supported by the family of his girlfriend at the time. This constructed family assembled at the graduation ceremony:

Couple of carers came. Um, Mum came. ... my then girlfriend's dad came ... It was pretty cool. (Pascal, lines 736-740)

Anja, by contrast, cut off contact with her family at an early age and never saw the carers working in youth welfare as relevant attachment figures. However, she did describe living together in all-girl group home as a "big family" where they lived "like sisters", stating, "You don't necessarily need parents as long as your sisters are there (laughs)." Living in a group home gave 
her a feeling of belonging. After leaving care, she developed a similar feeling of belonging with her friends: "I built up my group of best friends, that's my family." Anja was given practical support by a friend's mother, who helped her with tasks such as writing her CV and filling out job applications. In other words, Anja maintained her "doing family" on the level of informal peer relationships, though she still stressed that she has never experienced anything like real family life:

When I, um, was invited over to friends' families, it was new to me. It was funny, you know. (Anja, lines 722-723)

While care leavers typically lack relevant support from their parents when it comes to achieving educational goals, links may be found to other family members, usually siblings. Martin, whose partner motivated him to go to evening school, emphasised that his older sister was even closer to him than his girlfriend, stating that his sister showed him "going to university isn't just for highly intelligent people, but that I — or that we — can do that kind of thing."

Dalia listed two distant aunts as important attachment figures. She grew up on a farm, and her parents did not support her interest in technical training, which created family conflicts and ultimately led to Dalia being placed in out-of-home care. Some time after leaving care, she followed a roundabout educational route and ended up graduating with a Matura at a technically focused evening school. She described her aunt, who lived abroad and was the odd one out in the family, as her role model:

She's out in [a European country] now, she's a project manager. And she's my role model for what I want to be, and yes, she did a technical apprenticeship.... She always said like, "You'll do it." And she always said, "I'll make it somehow".... And my other aunt in [city] also said, "You're, you're a phenomenon." They were like kind of the two people, people I turned to, who were always behind me. //Mhm.// When afterwards my family said like, "Huh, you'll never make it anyway." (Dalia, lines 830-841)

\section{Discussion and Practical Implications}

Using the example of care leavers' educational pathways, our study revealed how family relationships influence their way of life, their outlook on the future, and how they establish social ties. For young people with experience of youth care, the status passage of leaving care is a prominent transitional phase during which they reexamine their previous life experiences and inclinations (Wade, 2008). Reliable, continuous, social ties are not common during this phase (Theile, 2015). After young people leave care, social ties from their time in care and informal relationships with carers or foster parents seem to quickly dwindle in importance. At the same time, research findings show that social relations play an important role for resilience and for a successful transition to adulthood (Goyette, 2019). When faced with living alone, care leavers focus on different aspects of family. Often, the family represents an imaginary model of belonging, mutual care and support, and a feeling of continuity and permanence. 
During the transition to independent living, whether or not care leavers cultivate their family relationships, and in what way, depends on their individual background and experiences. Reexamining their experiences of family, which necessarily includes their history of youth care, can revive stressful memories and conflicts. Many get back in touch with family members, while some finally break off contact once and for all (Mendes et al., 2012). Others try to create a sense of belonging by entering into their own partnerships and starting their own families (Cameron et al., 2018). Despite the risk of instability, the latter is usually experienced as something positive, and can lead to them taking on responsibility for achieving their life goals, or sometimes reconnecting with their family of origin. A relationship with family is not necessarily a relationship with parents. Depending on care leavers' experiences of family, different family members, such as siblings, grandparents, or aunts and uncles, can take on important positions as people that they can turn to for support, or as role models or mentors.

The relevance of family relationships for care leavers has several consequences for child and youth welfare. First of all, it seems necessary to recognise the importance of family in the transition to independent living. In this context, it is constructive to apply approaches that have already been established in work with families and in family preservation (Sievers et al., 2015, pp. 135-139), as these may have already been used while the young people were in youth care to help them deal with their families of origin. One such approach is to identify and encourage positive developments in the family of origin, though it is never possible to fully overcome the fundamental conflict between the perspective of child protection and that of family support (Collins et al., 2008). In cases where the young people cannot or do not want to come into contact with their parents, it can be helpful to engage with the family past and any "residual" feelings of loyalty or connection, as a means of developing their own identities (Sievers et al., 2015, p. 139).

In addition, care leavers need to be supported in the positions they adopt in relation to the family network. If family connections are to be turned into supportive relationships, past and present conflicts need to be processed. Moreover, reflecting on their own family histories can lead to a "sense of personal continuity" that is important for identity formation (Mann-Feder, 2019). To this end, it can be helpful to provide support to care leavers in the form of counselling, discussion, or therapy. Most care leavers see the established forms of aftercare as insufficient (Häggman-Latila et al., 2018). Considering the ambivalent nature of family relationships, it seems advisable to enable care leavers to stay in contact with professional carers, as well as setting up contact centres and support services during and after the status passage of leaving care.

Finally, in order to support sustainable relationship structures, a sensitivity to an individual's specific relationships with family members is needed. To achieve this, one must look beyond parent-child relationships to reveal other family members who could be relevant attachment figures. In this context, grandparents (Attar-Schwartz \& Huri, 2019) and siblings (Sting, 2014) are especially important, yet still receive too little attention in child and youth welfare. 
International Journal of Child, Youth and Family Studies (2020) 11(4.2): 140-159

\section{References}

Adjei, P. B., \& Minka, E. (2018). Black parents ask for a second look: Parenting under 'White' child protection rules in Canada. Child and Youth Services Review, 94, 511-524. doi:10.1016/j.childyouth.2018.08.030

Arnett, J. J. (2019). Foreword. In V. R. Mann-Feder \& M. Goyette (Eds.), Leaving care and the transition to adulthood (pp. XII-XX). Oxford University Press.

Arnett, J. J. (2000). Emerging adulthood: A theory of development from the late teens through the twenties. American Psychologist, 55(5), 469-480. doi:10.1037/0003-066X.55.5.469

Arnett, J. J. (2007). Afterword: Aging out of care - Toward realizing the possibilities of emerging adulthood. New Directions of Youth Development, 113, 151-161.

doi:10.1002/yd.207

Attar-Schwartz, S., \& Huri, Y. (2019). Grandparental support and life satisfaction among adolescents in residential care. Child and Youth Services Review, 96, 70-78.

doi:10.1016/j.childyouth.2018.11.033

Bauer, P., \& Wiezorek, C. (2017). Familienbilder zwischen Kontinuität und Wandel. Einleitende Bemerkungen [Family images between continuity and change. Introductory remarks]. In P. Bauer \& C. Wiezorek (Eds.), Familienbilder zwischen Kontinuität und Wandel: Analysen zur (sozial-)pädagogischen Bezugnahme auf Familie (pp. 7-22). Beltz Juventa.

Bauer, P., Neumann, S., Sting, S. Ummel, H., \& Wiezorek, C. (2015). Familienbilder und Bilder >guter< Elternschaft. Zur Bedeutung eines konstitutiven, aber vernachlässigten Moments pädagogischer Professionalität [Family images and images of "good parenting": On the importance of a constitutive but neglected moment of educational professionalism]. In S. Fegter, C. Heite, J. Mierendorff, \& M. Richter (Eds.), Neue Aufmerksamkeiten für Familie. Diskurse, Bilder und Adressierungen in der Sozialen Arbeit [Sonderheft 12] (pp. 25-37). Neue Praxis.

Bohnsack, R., Nentwig-Gesemann, I., \& Nohl, A. M. (Eds.). (2007). Die dokumentarische Methode und ihre Forschungspraxis. Grundlagen qualitativer Sozialforschung [The documentary method and its research practice: Basics of qualitative social research].VS Verlag für Sozialwissenschaften.

Bohnsack, R., Pfaff, N., \& Weller, W. (2010). Reconstructive research and documentary method in Brazilian and German educational science: An introduction. In R. Bohnsack, N. Pfaff, \& W. Weller (Eds.), Qualitative analysis and documentary method in international educational research (pp. 7-38). Barbara Budrich. https://nbn-resolving.org/urn:nbn:de:0168-ssoar$\underline{317253}$ 
International Journal of Child, Youth and Family Studies (2020) 11(4.2): 140-159

Brake, A., \& Büchner, P. (2011). Bildungsort Familie. Habitusgenese im Netzwerk gelebter Famillienbeziehungen [Family as a place of education: Habitus genesis in the network of lived family relationships]. In A. Lange \& M. Xyländer (Eds.), Bildungswelt Familie:

Theoretische Rahmung, empirische Befunde und disziplinäre Perspektiven (pp. 142-166). Juventa.

Cameron, C., Hollingworth, K., Schoon, I., van Santen, E., Schöer, W., Ristikari, T., Heino, T., \& Pekkarinen, E. (2018). Care leavers in early adulthood: How do they fare in Britain, Finland and Germany? Children and Youth Services Review, 87, 163-172. doi:10.1016/j.childyouth.2018.02.031

Care Leaver e. V. (2019). Unsere Rechte-Unsere Forderungen. Zukunftsorientierung statt Defizitblick [Our rights — our demands: Future orientation instead of a deficit view]. http://www.careleaver.de/wp-content/uploads/2013/09/Flyer.pdf

Care Leavers' Association. (2019). What is a care leaver? http://www.careleavers.com/who-weare/what-is-a-care-leaver-2

Collins, M. E., Paris, R., \& Ward, R. L. (2008). The permanence of family ties: Implications for youth transitioning from foster care. American Journal of Orthopsychiatry, 78(1), 54-62. doi:10.1037/0002-9432.78.1.54

Cyprian, G. (2003). Familienbilder als Forschungsthema [Family images as a research topic]. In G. Cyprian \& M. Heimbach-Steins (Eds.), Familienbilder. Interdisziplinäre Sondierungen (pp. 9-19). Leske + Budrich.

Dörr, M., \& Müller, B. (2012). Einleitung: Nähe und Distanz als Strukturen der Professionalität pädagogischer Arbeitsfelder [Introduction: Proximity and distance as structures of professionalism in pedagogical fields of work]. In M. Dörr \& B. Müller (Eds.), Nähe und Distanz. Ein Spannungsfeld pädagogischer Professionalität (pp. 7-29). Juventa.

Driscoll, J. (2013). Supporting care leavers to fulfil their educational aspirations: Resilience, relationships and resistance to help. Children \& Society, 27, 139-149. doi:10.1111/j.1099$\underline{0860.2011 .00388 . x}$

Eßer, F., \& Köngeter, S. (2012). Doing Family in der Heimerziehung. Familialität als professionelle Deutungsressource [Doing family in residential care: Familiality as a professional resource for interpretation]. Sozial Extra, 7-8, 37-40. doi:10.1007/s12054-0120084-9

Goyette, M. (2019). Social networks and social support in the transition to adulthood: A reflection on social integraion processes. In V. R. Mann-Feder \& M. Goyette (Eds.), Leaving care and the transition to adulthood (pp. 31-49). Oxford University Press. 
International Journal of Child, Youth and Family Studies (2020) 11(4.2): 140-159

Gradaílle, R., Montserrat, C., \& Ballester, L. (2018). Transition to adulthood from foster care in Spain: A biographical approach. Children and Youth Services Review, 89, 54-61. doi:10.1016/j.childyouth.2018.04.020

Groinig, M., Hagleitner, W., Maran, T., \& Sting, S. (2019). Bildung als Perspektive für Care Leaver? Bildungschancen und Bildungswege junger Erwachsener mit Kinder- und Jugendhilfeerfahrung [Education as a perspective for care leavers? Educational opportunities and pathways for young adults with child and youth welfare experience]. Barbara Budrich.

Groinig, M., \& Sting, S. (2019). Educational pathways in and out of child and youth care. The importance of orientation frameworks that guide care leavers' actions along their educational pathway. Child and Youth Services Review, 101, 42-49. doi:10.1016/j.childyouth.2019.03.037

Großegger, B. (2011). Familie, Freunde/innen, Szene: Beziehungskulturen im jugendlichen Alltag [Family, friends, scene: Relationship cultures in young people's everyday life]. In Bundesministerium für Wirtschaft, Familie und Jugend (Eds.), 6. Bericht zur Lage der Jugend in Österreich (pp. 199-227). https://www.frauen-familien-

jugend.bka.gv.at/service/publikationen/jugend/6-bericht-zur-lage-der-jugend-in-oesterreich$\underline{\text { 2011.html }}$

Häggman-Laitila, A., Salokekkilä, P., \& Karki, S. (2018). Transition to adult life of young people leaving foster care: A qualitative systematic review. Child and Youth Services Review, 95, 134-143. doi:10.1016/j.childyouth.2018.08.017

Hollstein, B. (2006). Qualitative Methoden und Netzwerkanalyse - ein Widerspruch [Qualitative methods and network analysis - a contradiction]? In B. Hollstein \& F. Straus (Eds.), Qualitative Netzwerkanalyse (pp. 11-35). VS Verlag für Sozialwissenschaften. doi:10.1007/978-3-531-90074-2__1

Hücker, F.-J. (2014). Treibsandkinder. Die vergessenen Kinder psychisch kranker Eltern [Quicksand children. The forgotten children of mentally ill parents]. Sozial Extra, 4, 6-11. doi:10.1007/s12054-014-0099-5

Hurrelmann, K., \& Quenzel, G. (2016). Lebensphase Jugend [Youth: A phase of life]. Beltz Juventa.

Jurczyk, K. (2014). Familie als Herstellungsleistung. Hintergründe und Konturen einer neuen Perspektive auf Familie [Family as a manufacturing achievement: Backgrounds and contours of a new perspective on family]. In K. Jurczyk, A. Lange, \& B. Thiessen (Eds.), Doing Family (pp. 50-70). Beltz Juventa.

Jurczyk, K., Lange, A., \& Thiessen, B. (2014). Doing Family als neue Perspektive auf Familie [Doing Family as a new perspective on family]. In K. Jurczyk, A. Lange, \& B. Thiessen (Eds.), Doing Family (pp. 7-48). Beltz Juventa. 
International Journal of Child, Youth and Family Studies (2020) 11(4.2): 140-159

Kasten, H. (2003). Geschwister. Vorbilder, Rivalen, Vertraute [Brothers and sisters: Role models, rivals, confidants]. Reinhardt.

Knight, A., Chase, E., \& Aggleton, P. (2006). Teenage pregnancy among young people in and leaving care: Messages and implications for foster care. Adoption \& Fostering, 30(1), 58-69. doi: $10.1177 / 030857590603000108$

Lange, A., \& Xyländer, M. (2011). Bildungswelt Familie: Disziplinäre Perspektiven, theoretische Rahmungen und Desiderate der empirischen Forschung [The educational world of the family: Disciplinary perspectives, theoretical frameworks and desiderata of empirical research]. In A. Lange \& M. Xyländer (Eds.), Bildungswelt Familie: Theoretische Rahmung, empirische Befunde und disziplinäre Perspektiven (pp. 23-94). Juventa.

Leitner, S., Loch, U., \& Sting, S. (2011). Geschwister in der Fremdunterbringung. Fallrekonstruktionen von Geschwisterbeziehungen in SOS-Kinderdörfern aus der Sicht von Kindern und Jugendlichen [Siblings in out-of-home care. Case reconstructions of sibling relationships in SOS Children's Villages from the perspective of children and young people]. LIT.

Maack, L. (2013). Familienunterstützung ohne Familie? Care Leaver und „doing family“ [Family support without a family? Care leaver and "doing family"]. Sozial Extra, 9-10, 47 49. doi:10.1007/s12054-013-1060-8

Mann-Feder, V. R. (2019). How can I be a real adult? Developmental theory as a framework for practice, policy, and research on care leaving. In V. R. Mann-Feder \& M. Goyette (Eds.), Leaving care and the transition to adulthood (pp. 9-30). Oxford University Press.

Marion, E., \& Paulsen, V. (2019). The transition to adulthood from care: A review of current research. In V. R. Mann-Feder \& M. Goyette (Eds.), Leaving care and the transition to adulthood (pp. 107-129). Oxford University Press.

Mendes, P., Baidawi, S., \& Snow, P. (2014). Young people transitioning from out-of-home care: A critical analysis of leaving care policy, legislation and housing support in the Australian state of Victoria. Child Abuse Review, 23, 402-414. doi:10.1002/car.2302

Mendes, P., Johnson, G. \& Moslehuddin, B. (2012). Young people transitioning from out-ofhome care and relationships with family of origin: An examination of three recent Australian studies. Child Care in Practice, 18, 357-370. doi:10.1080/13575279.2012.713849

Menz, S. (2009). Familie als Ressource. Individuelle und familiale Bewältigungspraktiken junger Erwachsener im Übergang in Arbeit [Family as a resource. Individual and familial coping practices of young adults in transition to work]. Juventa. 
International Journal of Child, Youth and Family Studies (2020) 11(4.2): 140-159

Narciso, I, Relvas, A. P., Ferreira, L. C., Vieira-Santos, S., Fernandes, M., de Santa-Bárbara, S., \& Machado, I. (2018). Mapping the "good mother": Meanings and experiences in economically and socially disadvantaged contects. Child and Youth Services Review, 93, 418427. doi:10.1016/j.childyouth.2018.08.029

Nestmann, F., Günther, J., Stiehler, S., Wehner, K., \& Werner, J. (Eds.). (2008). Kindernetzwerke. Soziale Beziehungen und soziale Unterstützung in Familie, Pflegefamilie und Heim [Children's networks: Social relationships and social support in the family, foster family and residential care]. dgvt-Verlag.

Nohl, A.-M. (2017). Interview und Dokumentarische Methode. Anleitungen für die Forschungspraxis [Interview and documentary method: Instructions for research practice]. VS Verlag für Sozialwissenschaften.

Peuckert, R. (2007). Zur aktuellen Lage der Familie [On the current situation of the family]. In J. Ecarius (Ed.), Handbuch Familie (pp. 36-56). VS Verlag für Sozialwissenschaften. doi:10.1007/978-3-531-90675-1_3

Refaeli, T. (2017). Narratives of care leavers: What promotes resilience in transitions to independent lives? Children and Youth Services Review, 79, 1-9. doi:10.1016/j.childyouth.2017.05.023

Richter, M. (2016). Familie und (gute) Elternschaft im Fokus neuer Aufmerksamkeiten. Ressource oder Risiko [Family and (good) parenting in the focus of new attentions. Resource or risk]? Sozial Extra, 6, 33-35. doi:10.1007/s12054-016-0112-2

Schmidt, U., \& Moritz, M.-T. (2009). Familiensoziologie. Transcript.

Schneewind, K. A. (2010). Familienpsychologie. Kohlhammer.

Schröer, W. (2011). Zur Entgrenzung von Jugend. Jugendsozialisation im digitalen Kapitalismus [On the blurred boundaries of youth. Youth socialization in digital capitalism]. In S. Sting \& V. Wakounig (Eds.), Bildung zwischen Standardisierung, Ausgrenzung und Anerkennung von Diversität (pp. 201-212). LIT.

Schröer, W. (2013). Entgrenzung, Übergänge, Bewältigung [Blurred boundaries, transitions, coping]. In W. Schröer, B. Stauber, A. Walther, L. Böhnisch, \& K. Lenz (Eds.), Handbuch Übergänge (pp. 64-78). Beltz Juventa.

Segalen, M. (2009). Questions about the contemporary family in Europe. In O. Kapella, C. RillePfeiffer, M. Rupp, \& N. F. Schneider (Eds.), Die Vielfalt der Familie (pp. 55-63). Barbara Budrich. 
International Journal of Child, Youth and Family Studies (2020) 11(4.2): 140-159

Sievers, B., Thomas, S., \& Zeller, M. (2015). Jugendhilfe - und dann? Zur Gestaltung der Übergänge junger Erwachsener aus stationären Erziehungshilfen [Youth welfare - and then? To design the transitions of young adults from out-of-home-care]. Internationale Gesellschaft für erzieherische Hilfen (IGFH).

Statista. (2019). Durchschnittsalter junger Menschen* beim Verlassen des elterlichen Haushalts nach Geschlecht in Ländern Europas im Jahr 2019 [Average age of young people when leaving their parents' household in Europe in 2019, by gender]. https://de.statista.com/statistik/daten/studie/73631/umfrage/durchschnittliches-alter-beimauszug-aus-dem-elternhaus

Stauber, B., \& Walther, A. (2013). Junge Erwachsene - eine Lebenslage des Übergangs [Young adults: A life situation of transition]? In W. Schröer, B. Stauber, A. Walther, L. Böhnisch, \& K. Lenz (Eds.), Handbuch Übergänge (pp. 270-290). Beltz Juventa.

Stein, M. (2008). Transitions from care to adulthood: Messages from research for policy and practice. In M. Stein \& E. R. Munro (Eds.), Young people's transitions from care to adulthood (pp. 289-306). Jessica Kinsley.

Steiner, M., Pessl, G., \& Bruneforth, M. (2016). Früher Bildungsabbruch - Neue Erkenntnisse zu Ausmaß und Ursachen [Early drop-out: New insights into the extent and causes]. In M. Bruneforth, F. Eder, K. Krainer, C. Schreiner, A. Seel, \& C. Spiel (Eds.), Nationaler Bildungsbericht Österreich 2015 (pp. 177-221). Leykam.

Sting, S. (2014). Geschwisterbeziehungen bei außerhalb der Herkunftsfamilie lebenden Kindern und Jugendlichen [Sibling relationships in children and young people living in out-of-home care]. In K. Bock, A. Kupfer, R. Simon, K. Weinhold, \& S. Wesenberg (Eds.), Beratung und soziale Beziehungen (pp. 196-206). Beltz Juventa.

Sulimani-Aidan, Y. (2018). Assets and pathways in achieving future goals of residential alumni. Children and Youth Services Review, 89, 71-76. doi:10.1016/j.childyouth.2018.04.023

Sulimani-Aidan, Y, \& Melkman, E. (2018). Risk and resilience in the transition to adulthood from the point of view of care leavers and case workers. Children and Youth Services Review, 88, 135-140. doi:10.1016/j.childyouth.2018.03.012

Theile, M. (2015). Soziale Netzwerkbeziehungen als Ressouce. Soziale Beziehungen im Lebenslauf von Jugendlichen in der Heimerziehung [Social network relationships as a resource: Social relationships in the biography of young people in residential care]. Universitätsverlag Siegen Zentrum für Planung und Evaluation Sozialer Dienste.

Thiersch, H. (2012). Nähe und Distanz in der Sozialen Arbeit [Proximity and distance in social work]. In M. Dörr \& B. Müller (Eds.), Nähe und Distanz. Ein Spannungsfeld pädagogischer Professionalität (pp. 32-49). Juventa. 
International Journal of Child, Youth and Family Studies (2020) 11(4.2): 140-159

Thomas, S. (2013). Erwachsenwerden in stationären Erziehungshilfen [Growing up in out-ofhome care]. PFAD, 4, 12-13.

van Breda, A. D., \& Dickens, L. (2017). The contribution of resilience to one-year independent living outcomes of care-leavers in South Africa. Child and Youth Services Review, 83, 264273. doi:10.1016/j.childyouth.2017.11.009

Wade, J. (2008). The ties that bind: Support from birth families and substitute families for young people leaving care. British Journal of Social Work, 38, 39-54. doi:10.1093/bjsw/bcl342

Ward, H. (2008). Legal and policy frameworks. In M. Stein \& E. R. Munro (Eds.), Young people's transitions from care to adulthood (pp. 258-278). Jessica Kinsley.

Weinhardt, M. (2014). Biographie, Lebenslauf und Übergänge in der Beratung [Biography, curriculum vitae and transitions in counseling]. Resonanzen. E-Journal für biopsychosoziale Dialoge in Psychotherapie, Supervision und Beratung, 2(1), 34-48. https://www.resonanzenjournal.org/index.php/resonanzen/article/view/267

Witzel, A. (2000). Das problemzentrierte Interview [25 Absätze; The problem-centred interview; 25 paragraphs]. Forum Qualitative Sozialforschung/Forum: Qualitative Social Research, 1(1), Art. 22. doi:10.17169/fqs-1.1.1132 